Kohl: a Journal for Body and Gender Research

Vol. 6, No. 1 (Summer 2020)

\title{
A Map of Silence, and the Spaces Between
}

\author{
Leila Abdelrazaq
}


The final time we filed up the Detroit courthouse steps, I had already moved there. We filtered in as always, the clatter of keys and belts in plastic bins echoing through the great stone hall as gloved guards felt us up. Before he handed down her deportation order, Judge Drain told Rasmea to read her final statement. As she spoke, tears swelled in the back of my throat. I expected a moving, personal account, but her speech read more like a slogan-laden Wikipedia article on the Palestinian struggle. A voice in my ear whispered: "Rasmea didn't write this." I came to the unwilling realization that she had been silent long before the judge ordered her to stop speaking.

Afterwards, the picket line circled up and down Lafayette in that reliable oval, single-file, well-spaced. I had marched vigilantly in that line for so many years, had chanted until my voice grew hoarse, in bitter cold and unrelenting rain, days when thousands of tiny droplets formed shimmering wet halos around our heads and we called out, "I believe that we will win." Jumping up and down, fingertips pressed into one-another's shoulders, we were fish thrashing forward in an enormous, yet unseen net. In those days, we pulled hope out of one-another's throats, too terrified to discuss any alternative ending to the story that was unfurling around us. We weren't prepared for everything to fall apart. We placed our faith in the slogans. They became a kind of great communal prayer, as if repeating them would speak into existence some semblance of justice.

That last day, the chanting crowd on the sidewalk in front of the courthouse looked to me as much a circus as the inside of the judge's marble chambers. Men I knew to be violent spoke self-righteously of women's liberation. The four-year campaign to keep Rasmea Odeh, the then 70-year-old Palestinian community organizer, from being deported due to her activism, had become a crowning feminist jewel in the political careers of the men at the helm of the effort. In their quest for the perfect woman-centered Palestinian liberation project, these men had left countless women strewn along in their wake, women who were, ultimately, sent far, far away.

That day, after the speeches and the cameras left us in a daze, I stood and watched everyone board the bus I had taken so many times. I remembered how we'd clamor up the tall rubber-coated steps in the mosque parking lot before the sun, resting our heads against the cool windows as we careened down I-94, that artery that connects our twin cities flitting by outside the window. On those long rides between Chicago and Detroit, friendships and alliances had blossomed and imploded and continually transformed, but still we all boarded that bus together in an ever-changing game of musical chairs set to the tune of Palestinian wedding songs, the crinkle of plastic water bottles, and popping potato chip bags. By the time we'd return to Chicago later that same evening, it would be dark as when we'd left.

On that last day, I watched the bus roll away before walking to my car. The sun spilled streams of golden light along the rooftops of my new city

** 
Nour's house, at some point during those years, had become my Detroit home away from home. One morning in late April, a group of us sat on their second-story porch in our pajamas, looking out over overgrown lawns. As we sipped hot coffee and watched the neighborhood rise, I felt the words balloon in my chest and tumble out of my mouth before I could think. "I'm going to move here." Nour was silent for a moment. I watched their unflinching face carefully for a response. At last, they replied. "Yeah? Finally."

When I got back to Chicago that evening, I texted a friend asking to get breakfast the following morning, because I had something important to tell her. The next day, as we slid into the orange vinyl booth in that Northwest Side diner, she blurted, "You're moving to Detroit." I grinned. "How did you know?" She shrugged, looking sideways out the window. "I saw an Instagram story. You were sitting with a group of people in a backyard, drinking arabi coffee and talking about Palestinian art. When I saw the video, I knew, they stole my bitch."

\section{**}

Political exile is a strange thing. Suddenly, the people who had made you feel indispensable dispose of you. You spend long nights together planning sit-ins and teach-ins, meetings and marches. You convince yourself that these people are family. But one day, something happens. Maybe you try to hold the wrong person accountable, or ask the wrong kind of question. And suddenly, as quickly as you were embraced all those years ago, the people you thought would be there for you no matter what begin to spiral away. Slowly, you're invited to fewer meetings. Suddenly, you're alone, the wrong kind of political dissident.

Moving to Detroit was the final step, and it was an exile of my own making, something I had agency over. One evening, in the weeks after my move, I was laying on Kamelya's bedroom floor, talking to her about everything that had happened in Chicago, and found myself in tears. "One thing I realized when I was in Chicago for Rasmea's goodbye celebration," she said, "is that your ass has been knee-deep in Chicago Palestine organizing. But listen to me:" She looked me in the eyes. "You're in Detroit now, baby."

Detroit became the city where I learned to let myself dance, in the darkness of bars and DIY clubs where techno pounded in our chests and pressed our bodies in close. In Detroit I fell in love, for the first time, with someone who loved me back, and we fought for one-another with a ferocity and commitment that I had never known was possible outside of political work. Detroit, the city that had made so many exiles, had become a refuge of sorts for exiles of another kind. I still can't decide if this reality is a perverse one or not, but it is the truth. We, exiles of our exiled communities, whose viewpoints were not in line with those of our institutions, whose shorts were too short, who wore the wrong clothes and colors for our assigned genders, whose career paths strayed from expectations, had found a space here. We were poets and painters, mathematicians and musicians.

Detroit is a city that teaches community support in ways that Chicago didn't for me. Here, we cooked iftar for one-another during Ramadan, comparing ancient family recipes we were still learning to make. Cold winter 
days, we gathered in The Bottom Line to read aloud bilingual poetry and the bottoms of our qahwi cups, and

when the place was nearly shuttered by debt, everyone pitched in to keep it open. When friends lost their homes to developers, couches became landing pads. In winter, we helped to buzz each other's hair in bathrooms; come summer, we moved to back porches. Evenings, when we grew tired from dancing, we smoked cigarettes on the sidewalk, then helped each other quit, then started again. We drew for one-another tattoos of the fruits of our homelands, of split-open figs and sunflowers, olive branches and orange blossoms. We embedded into our flesh inky reminders of the places our families had left behind, made them a permanent part of ourselves, they were sacred symbols, static and unchanging as our romanticized views of the places and ideas they had come to represent.

Community support as survival tactic: a tradition that our people had known, long ago, then forgot, to an extent, in the great gaping maw of American individualism, then re-learned again from Detroit, one of those rare American cities that told us it was okay to be ourselves, that said we didn't have to apologize, that affirmed to us that we didn't owe this empire a damn thing.

**

Shortly before I decided to move, I met an old friend for lunch in downtown Chicago. I couldn't remember the last time I saw her. We caught up over rice bowls, sharing the mundane details of our lives that had transpired in the intervening months of radio silence. Finally, I said it. "I feel like you guys stopped including me because of him," I told her. "When you invite him, you don't invite me." She agreed that this was true, but only because when I was around, he acted obnoxious, became reckless and resistant, and all told. It was simply easier for everyone if I wasn't there. "That's kinda fucked up," I told her. "Yeah," she agreed. Nothing changed.

And these are the ways in which women, one by one, disappeared, slowly, before everyone's eyes, and to everyone's knowledge, after years of designing posters we never signed our names on, drafting agendas for meetings we didn't lead, and figure heading campaigns designed to cannibalize us. We were happy to play these roles, until one day, we reached into our seemingly infinite wells of power and energy and found that we who had poured ourselves into bottomless cups had nothing left to give, and the movement disposed of us. If the men whose careers our work sustained abused or exploited us, we kept quiet, to spare their reputations, to spare our reputations, to avoid creating "drama," to avoid making "the movement" more vulnerable than it already was. And so, we disappeared, and watched as new women emerged in our place, eyes alight and ready to pick up where we had left off, and we whispered to one-another how we were worried for them, but still, we kept silent.

Here is the paradox: If you speak up, everyone else will exile you. If you keep quiet, you have no choice but to exile yourself. Choose your weapon. 
I had nightmares for months in which people I had formerly organized with in Chicago twisted and turned into monsters. I heard whispers that those same people were being surveilled and stalked by powerful law enforcement agencies, and I kept my mouth shut. A few months after my move, Rasmea was deported to Jordan. I clicked through an album of photos of my friends tearfully sending her off at O'Hare. I felt glad l'd said goodbye to her personally before I left Chicago, sparing myself from yet another grotesque public spectacle. I spent hours pouring my heart into long, angry Facebook rants. I'd craft them meticulously and post them for the thrill, then delete them seconds later, a ritual of sorts, dissolving my grievances into cyberspace.

**

I think a lot about how many times Rasmea has experienced exile, like it's just that easy and suddenly you don't belong anywhere, you have no country, and no country wants you, and it makes me want to destroy my passport but the irony is that this thing that says I'm not of Palestine is also the only thing that will get me into Palestine, and maybe one of the only things giving me freedom of movement as a Palestinian, but at the end of the day fuck a nationality, it's nationalism that got us here, after all, and for now Detroit is where l'll stay, maybe, until it spits me back out, (it wouldn't be the first time), or until I spit me back out, (it wouldn't be the last).

Exile as a place of residence, a tradition of sorts. Maybe I'm more at home here, in the in-between. It's the paradox of the graveyard in my family's refugee camp, my jiddo entombed forever between the low cinderblock walls of a temporary shelter. So, I like it here in exile, the only thing that never changes.

These are among the most important things I think I have figured out in Detroit: That homes are rarely permanent. That it's okay. That a person can be exiled multiple times, in multiple ways. That you can survive. That Detroit, for some, may be what Chicago was for me, and vice versa. That Detroit, in part, is a city of exile. That it doesn't have to be. That for some of us, to call a place "home" is a radical political act. That it shouldn't have to be. That Rasmea came to Chicago by way of Detroit, and it is this fact that led me to Detroit by way of Chicago. 